\title{
905 引張りおよび引張り一ねじり試験によるブタ前十字勒帯の力学的特性評価
}

\section{Biomechanical Evaluation of Anterior Cruciate Ligament by Tensile and Tensile-Torsional Tests}

\author{
学 ○高柳 津富 (新潟大院) \\ 正坂本 信 (新潟大医) \\ 正 小林 公- (新潟大医) \\ 正田邊 裕治（新潟大工）
}

Tsutomu TAKAYANAGI, Graduate School of Science and Technology, Niigata University

Ikarashi 2-8050, Niigata, Japan

Koichi KOBAYASHI, Dept. of Health Sciences, Niigata University School of Medicine Makoto SAKAMOTO, Dept. of Health Sciences, Niigata University School of Medicine Yuji TANABE, Dept. of Mechanical and Production Engineering, Niigata University

Key words: Biomechanics, ACL, Femur-ACL-Tibia Complex, Tension, Tension-torsion, Failure Load

\section{1. 緒 言}

勒帯は関節において骨同士を結ぶ結合組織であり，安定 な関節運動を実現する上で重要な役割を担っている。臨床 的に勒帯の機能障害は過度の外力負荷による損傷および断 裂によって引き起こされることが多い，特に若年者の運動 時に多く見られる前十字勒帯 (Anterior Cruciate Ligament：以下 ACL）の損傷では受傷時の肢位が勒帯の ねじりを伴う膝関節の外反，外旋であることが多いので， $\mathrm{ACL}$ の損傷メカニズムを解明する上で，ねじり負荷がそ の強度特性にどの程度影響を与えるのか定量的に明らかに 寸ることは重要である。

$\mathrm{ACL}$ を含む勒帯組織の基礎的な生体力学的特性に関し ては従来生体外 ${ }^{(1)}$ (4) のみならず，生体内 ${ }^{(5)}$ 含数多くの 研究が報告されており，種々の知見が得られている。しか しながら，ねじり挙動についての報告例 ${ }^{(6) \sim(8)}$ は少なく, 詳細な特性は明らかにされていない。

そこで本研究では，ブタ大腿骨 $-\mathrm{ACL}$ 一脛骨複合体 (Femur-ACL-Tibia Complex : 以下 FATC) に対し, 引張 り試験とともに，引張り一稀じり試験を行い，最大引張り 荷重に及ぼすねじり負荷の影響について検討した。

\section{$2 \cdot 1$ 試験片}

\section{2. 実 験}

新鮮ブタ後肢から ACL 以外の軟部組織を除去した後, 大腿骨遠位端，脛骨近位端よりそれぞれ $100 \mathrm{~mm}$ で切断し FATC を作成した。大腿骨と脛骨それぞれの切断端から $50 \mathrm{~mm}$ 程度をステンレス製のカップに入れ，低融点合金

(Uアロイ, 融点 $47^{\circ} \mathrm{C}$ ) とボルトを用いて固定した。左 脚を引張り一ねじり試験用とし $(n=4)$ ，右脚を引張り試 験用とした $(n=3)$

\section{$2 \cdot 2$ 力学試験}

力学試験には 2 軸制御材料試験機（MTS 社製 $858 \mathrm{Mini}$ Bionixß II）を用いた（図 1)，図 2 に示すようにFATC がほぼ伸展位の状態でステンレスカップを試験機に固定し た。引張り試験は引張り速度約 $0.5 \mathrm{~mm} / \mathrm{sec} て ゙$ 実施した。 引 張りーねじり試験では引張り速度を約 $0.5 \mathrm{~mm} / \mathrm{sec}$ とし，ね じり角速度については生理学的条件を考虑し最大衫じり角 が概ね 15 度となるように $0.25 \mathrm{deg} / \mathrm{sec} に$ 設定した。試験機 が出力する荷重, 変位, トルクおよびねじり角度信号をパ ーソナルコンピュータに記録した。試験片加工中と力学的 試験中は潤湿状態を保った。全ての実験は室温中（約 $\left.20^{\circ} \mathrm{C}\right)$ で行った.

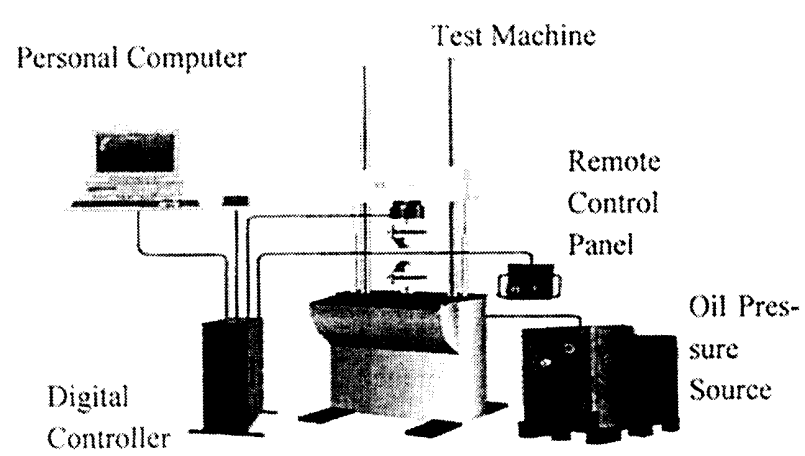

Fig1. Experimental setup.

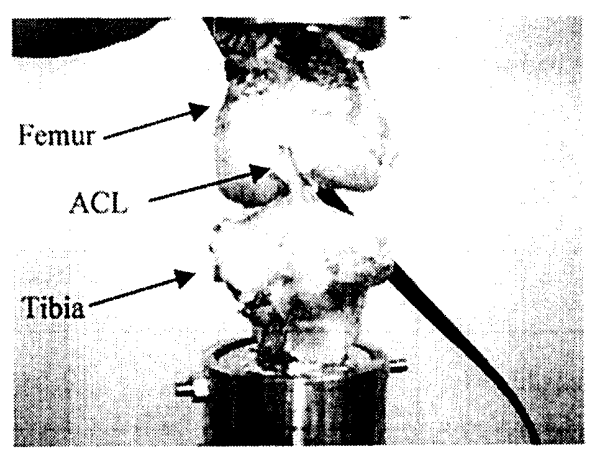

Fig. 2 Photograph of FATC attached to fixing device.

\section{3. 結 果}

図 3 に引張りおよび引張り一ねじり試験によって得られ た荷重一変位曲線の一例を示す。引張り試験の結果では, 最大荷重に達する前に一時的な荷重の低下が見られた。こ れは $\mathrm{ACL}$ 付着部の部分的な剥離による。引張り試験およ び引張りーねじり試験ともに最大荷重に達した後, 一旦低 下した荷重が再度上昇した。最大荷重時では完全な $\mathrm{ACL}$ の断裂もしくは付着部での剥離は起こらず, 再度荷重がピ 一クに達した時に完全な剥離が生じた。図 4 に図 3 に示し た引張りーねじり試験における荷重とトルクの時間変化を 示す。荷重の時間変化は図 3 に示したように二回ピークを 迎える特性を示したが，トルクの時間変化にはそれは見ら れず，ピークは一回だけであった。破断形態は引張り試験 では脛骨側での剥䧹，引張りーねじり試験では脛骨側での 


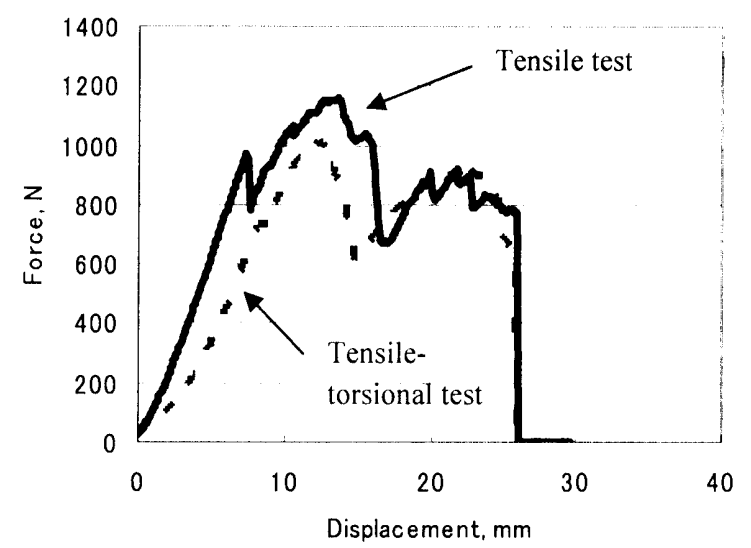

Fig.3 Load-displacement curves from tensile and tensiletorsional tests.

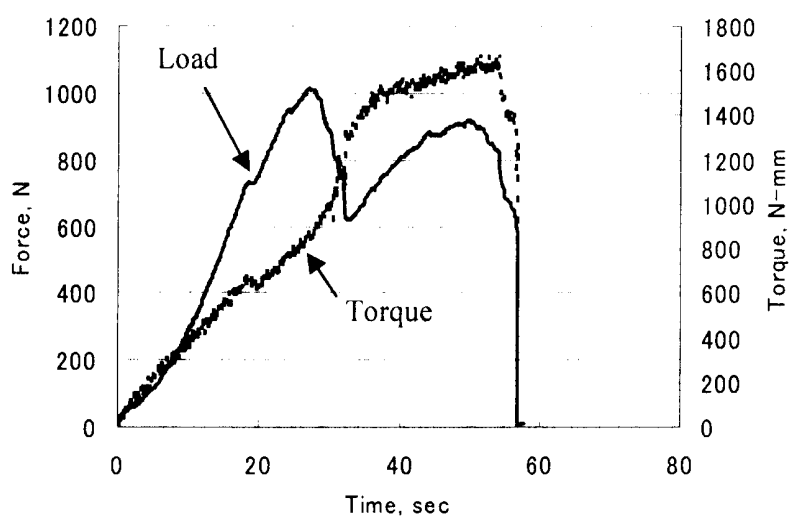

Fig.4 Load-time and torque-time relations of tensile-torsional test shown in Fig.3.

Tablel. Average and standard deviation of mechanical properties.

\begin{tabular}{|c|c|c|}
\hline & $\begin{array}{c}\text { Maximum } \\
\text { Load, } \mathrm{N}\end{array}$ & $\begin{array}{c}\text { Displacement at } \\
\text { maximum load, } \mathrm{mm}\end{array}$ \\
\hline Tensile test & $1132.4 \pm 155.8$ & $12.5 \pm 1.2$ \\
\hline $\begin{array}{c}\text { Tensile- } \\
\text { torsional test }\end{array}$ & $1033.3 \pm 60.3$ & $11.8 \pm 5.4$ \\
\hline
\end{tabular}

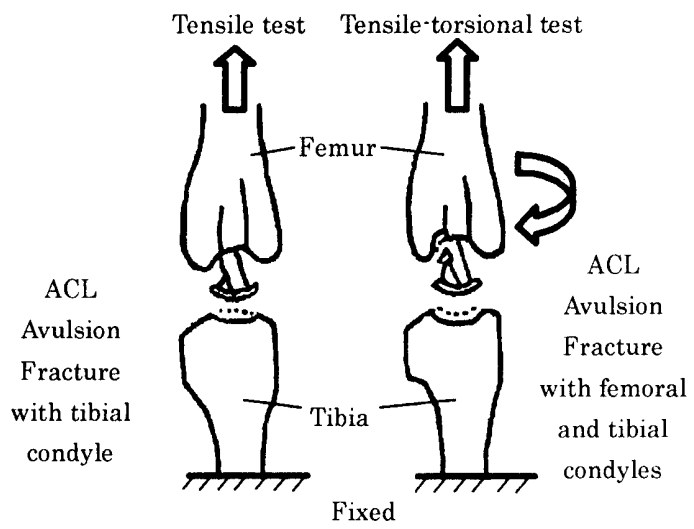

Fig.5 Schematic drawing of typical failure patterns of ACL by tensile and tensile-torsional tests.
剥離と同時に大腿骨側での剥離を伴った（図 5 ）。

表 1 に引張りおよび引張り一対じり試験による最大引張 荷重と最大引張荷重時での変位の平均値と標準偏差を示す 惢りの有無による統計学的有意差はなかった。

\section{4. 考 察}

運動時における $\mathrm{ACL}$ 受傷肢位の多くは膝関節の外旋, 外反であることが指摘されており，その際 ACL には引張 りに加えねじりも作用している。本研究では，このことを 考慮し引張り試験に加え, 引張り一ねじり試験を行った。 最大荷重は孙じりを加えた場合約 $10 \%$ 低下したが，統計

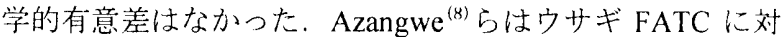
し引張り一㸚じり試験を行い, 最大引張り荷重と最大引張 り荷重時の変位は好じり負荷の影響を受けない上報告した。 この結果は本研究と一致している。破断形態について，称 じりを加えた場合，脛骨側と大腿骨側両方の付着部で剥離 したことについては付着部におけるせん断力が増加したた めと考えられる，今後，膝関節の屈曲角や荷重条件など実 験環境をより生理学的条件に近づけ，臨床における $\mathrm{ACL}$ の受傷形態と比較検討寸る必要がある。

\section{5. 結 言}

ブタ大腿骨 - ACL一脛骨複合体（FATC）に対し引張り および引張り一㸚じり試験を行い, 最大引張り荷重に及ぼ 寸ねじり負荷の影響について検討した。そその結果, 权じり 負荷による最大引張り荷重の有意な変化はなかった。破断 形態については引張り負荷時が脛骨付着部での剥離であっ たのに対し，引張りーねじり負荷時では大腿骨付着部の剥 離も伴った。

\section{文 献}

(1) Noyes F.R., Delucas J.L., Torvik P.J., Biomechanics of anterior cruciate ligament failure: An analysis of strain-rate sensitivity and mechanisms of failure in primates. $J$ Bone Joint Surg 56-A, 2(1974), 236-253.

(2) Noyes F.R., Grood E.S., The strength of the anterior cruciate ligament in humans and rhesus monkeys. $J$ Bone Joint Surg, 58-A(1976), 1074-1082.

(3) Butler D.L., Anterior cruciate ligament: Its normal response and replacement. J Orthop Res, 7(1989), 910-921.

(4) Butler D.L., Kay M.D., Stouffer, D.C., Comparison of material properties of fascicle-bone units from patellar tendon and knee ligaments. J Biomech, 19(1986), 425-432.

(5) Fleming B.C., et al, The effect of weightbearing and external loading on anterior cruciate ligament strain. J. Biomech, 34(2001), 163-170.

(6) Stouffer D.C., Butler D.L., Kim M., Tension-torsion characteristics of the canine anterior cruciate ligament-Part 1: Theoretical framework. ASME J. Biomech. Eng, 105(1983), 154-159.

(7) Butler D.L., Stouffer D.C., Tension-torsion characteristics of the canine anterior cruciate ligament-Part2: Experimental observations. ASME J. Biomech, 105(1983), 160-165.

(8) Azangwe G., Mathias K.J., Marshall D., The effect of torsion on the appearance of the rupture surface of the ACL of rabbits. Knee, 9(2002), 31-39. 